\title{
TOMASZ CIESIELSKI
}

Uniwersytet Opolski, Instytut Historii

E-Mail: tciesielski@uni.opole.pl

\author{
WHEN OTHER RULERS DEFEND \\ DISSIDENTS \\ THE SITUATION OF PROTESTANTS \\ AND ORTHODOX CHRISTIANS \\ IN THE POLISH-LITHUANIAN COMMONWEALTH \\ OF THE SAXON ERA
}

For as long as it existed, the Commonwealth was a multi-confessional country, with Catholicism prevailing as a result of both the number of followers and the applicable law. The latter, however, granted protection as well as a wide range of social, economic and cultural freedoms to followers of other religions, including the Muslims and the Jews. Greek Orthodox, Orthodox and Protestant followers also had quite substantial political rights guaranteed by applicable legal acts, with the Warsaw Confederation as the main example. Established at the convocation of the Sejm in 1573, it granted equal rights and protection of the state to members of other religions apart from Catholicism. Although it applied mainly to the nobility and on a larger scale to townspeople, the Warsaw Confederation was a unique phenomenon in Europe of the early modern era, as it was the first act guaranteeing religious tolerance within the law in an entire country. Applied in its entirety for over a century, it provided the Commonwealth with the status of a country where no outright religious persecution of religions other than Catholicism occurred.

Religious tolerance in the Commonwealth in the $16^{\text {th }}$ and $17^{\text {th }}$ centuries was and still is the subject of lively discussions, mainly among Polish, Lithuanian, Belarusian and Ukrainian historians, as well as from other Euro- 
pean countries. However, besides the mainstream discussions, there is still the issue related to the attempts at limiting social and religious freedoms of non-Catholics in the Commonwealth and to riots and massacres with a religious background. Significant increase in the limitations on public freedoms and the political rights of followers of other religions occurred in the Commonwealth during the reigns of two rulers of the Wettin dynasty. Research related to the Polish intolerance that lasted over half a century is somewhat unpopular among historians, not only from Poland, but also from the countries that feel a bond with the Commonwealth due to their common history (Lithuania, Belarus, and - with some reservations - Ukraine). This may come as no surprise since it shakes the myth of the tolerant state 'without the pyres' - to use a term introduced 50 years ago by Janusz Tazbir into the canon of thinking about the Commonwealth ${ }^{1}$. As a result, most Polish coursebooks contain only a few lines regarding the limitation of the rights of non-Catholics in the second half of the $17^{\text {th }}$ century and the first 70 years of the $18^{\text {th }}$ century, or at best a paragraph in chapters on the social-religious situation. Similarly, not many valuable articles or scientific monographs can be found. Apart from the works of Wojciech Kriegseisen, who attempted to present the situation of the Polish and Lithuanian Protestants in the so-called Saxon era in a general light, other publications focus on specific phenomena or incidents within the history of Polish intolerance ${ }^{2}$. The most popular ones include the Torun case in 1724, constituting a basis for the most frequent discussions on the international consequences of religious intolerance in the Commonwealth in the $18^{\text {th }}$ century. However, outside the mainstream discussions remains the question to what extent the internationalization of the Torun case and also other incidents was caused by intolerance in the Commonwealth as a result of intentional policies, subordinate to the interests of some European countries (especially Prussia, Russia and in the 1720s-40s, including England and the Netherlands) and to what extent it resulted from actions taken by Polish and Lithuanian religious dissidents who, deprived of the

${ }^{1}$ J. Tazbir, Państwo bez stosów. Szkice $z$ dziejów tolerancji w Polsce XVI i XVII wieku, (1967).

2 A main focus of his work is: W. Kriegseisen, Ewangelicy polscy i litewscy w epoce saskiej (1696-1763). Sytuacja prawna, organizacja i stosunki międzywyznaniowe, (1996). See also W. Kriegseisen, Between Intolerance and Persecution: Polish and Lithuanian Protestants in the 18 ${ }^{\text {th }}$ Century, in: Acta Poloniae Historica, 73 (1996), pp. 13-27. 
protection of their own king, sought justice and protection from Protestant and Orthodox monarchs.

This article constitutes an attempt at presenting the status of research within Polish historical science regarding the issue of intolerance in the Commonwealth during the period of the two Wettin rulers. It was created based of hand-written documents as well as printed ones, and of selected literature (see Bibliography). However, it is selective and does not describe the specific publications of selected historians. The results of their work, however, were presented in chronological order presenting the stages of Polish intolerance and the problem of its transformation into an international problem, impacting negatively on the image of the Commonwealth in the $18^{\text {th }}$ century's 'enlightened' Europe. A deliberate decision was made that the analysis would not use publications of historians from other countries, as they analyze the issue of intolerance in the Commonwealth from a completely different perspective, exaggerating the significance of the issue, especially the so-called Torun incident, as it is the case with German or British historiography. Meanwhile, it was just one of the incidents occurring in the history of Polish intolerance, with no groundbreaking significance.

In the years 1697-1763 the Polish-Lithuanian Commonwealth was under the reign of two kings of the House of Wettin, still viewed in Europe at the beginning of $18^{\text {th }}$ century as Protestants, and what is more, ruling one of the strongest Lutheran countries in the Roman-German Empire, the Electorate of Saxony. Although both of them converted to Catholicism, Augustus II (Frederick Augustus I, born 1670, died 1733; King of Poland and Grand Duke of Lithuania 1697-1733) in June 1697, and his son Frederick Augustus II (from January 1734 King of Poland and Grand Duke of Lithuania as Augustus III) when he was still a young prince in November $1712^{3}$, it could be expected that they would endeavour to restore in Poland the state of complete religious tolerance based on the articles of the so-called Warsaw Confederation of 1573. However, this did not happen, and

3 J. Staszewski, August II Mocny, (1998), pp. 54-58, 190-191; idem, August III Sas, (2010), pp. 54-64; J. Gierowski, Anglia wobec konwersji królewicza Fryderyka Augusta, in: Kultura staropolska - kultura europejska. Prace ofiarowane Januszowi Tazbirowi w siedemdziesiata rocznice urodzin, eds. S. Bylina et al., (1997), pp. 127-138; idem, Na szlakach Rzeczypospolitej w nowożytnej Europie, (2008), pp. 373-393; B. Krysztopa-Czupryńska, Rzeczpospolita w oczach dyplomatów brytyjskich w pierwszej połowie XVIII wieku, (2013), pp. 283-297. 
during the reign of Augustus II. the public rights of followers of religions other than Roman Catholicism were seriously limited. The reasons may be tracked down to the increasing xenophobia caused by various political, social and religious factors among the nobility dominated by Catholics. A crucial role here was played by the experiences of the Great Northern War, when Polish and Lithuanian lands were ravaged by a Lutheran Swedish army and an Orthodox Russian $\mathrm{army}^{4}$, the civil war of 1715-1716, where the opponent was the Saxon $a r m y^{5}$ and finally also the influence of the famine and plague in $1704-1714^{6}$.

All those factors contributed to the increase in religiousness among Catholics of all levels, from aristocrats and nobles, to city commoners and peasants. It found its expression in an increasingly ostentatious presentation of religiousness through participation in masses and services that sometimes,

${ }^{4}$ Regarding the situation of the Polish-Lithuanian Commonwealth during the Great Northern War see: J. Wimmer, Wojsko Rzeczypospolitej $w$ dobie wojny północnej (1700-1717), (1956); R. I. Frost, The Northern Wars, War, State and Society in Northeastern Europe, 1558-1721, (2000); J. Staszewski, Problemy tolerancji polskiej w czasach saskich, in: idem, “Jak Polskę przemienić w kraj kwitnący...”. Szkice i studia z czasów saskich, (1997), pp. 235-236.

5 [E. Otwinowski], Dzieje Polski pod panowaniem Augusta II od roku 1696-1728, [ed. A. Mułkowski], print J. Czech, (1849), pp. 231-311; A. Prochaska, Konfederacja tarnogrodzka, in: Przewodnik Naukowy i Literacki. Dodatek do "Gazety Lwowskiej", 45 (1917), 2: pp. 140-154, 3: 239-256, 4: 353-367, 5: 430-454, 6: 521-548, 7: 638-657, 8: 756-768, 9: 837-848, 10: 934-942; Konfederacja tarnogrodzka i jej tradycje, ed. R. Szczygieł, (1995), p. 15-53; J. Gierowski, Między saskim absolutyzmem a złotą wolnością. Z dziejów wewnętrznych Rzeczypospolitej w latach 1712-1715, (1953), pp. 286-315; J. Wimmer, Wojsko Rzeczypospolitej, pp. 410-428

${ }^{6}$ F. Giedroyć, Mór w Polsce w wiekach ubiegtych. Zarys historyczny, (1899), pp. 58-61; J. Kracik, Pokonać czarna śmierć, Staropolskie postawy wobec zarazy, (1991), pp. 101-116; E. Sieńkowski, Dżuma w Gdańsku w 1709 roku. Studium z dziejów epidemiologii, in: Archiwum Historii Medycyny, 33 (1970), pp. 309-401; S. Flis, Dżuma na Mazurach $i$ Warmii w latach 1708-1711, in: Komunikaty Mazursko-Warmińskie, 4 (1960), pp. 473-523; E. Karpacz, "Opłakane czasy" - epidemia dżumy w Krakowie w latach 1707-1710. Przyczynek do badań nad upadkiem królewskiego miasta, in: Folia Historica Cracoviensia, 18 (2012), pp. 239-256; Dżuma, ospa, cholera: w trzechsetna rocznice wielkiej epidemii w Gdańsku i na ziemiach Rzeczypospolitej w latach 1708-1711, ed. E. Kizik, (2012), pp. 21-22, 24, 63-64, 66, 73-74, 99-143 (scientific papers devoted to the Plague in Elbląg, Gdańsk, Toruń, Chłemno, East and West Prussia in the years $1707-1711$ by A. Karpiński, E. Kizik, K. Pękacka-Falkowska, J. Wijaczka and M. G. Zieliński); A. Perłakowski, Jan Jerzy Przebendowski jako podskarbi wielki koronny (1703-1729), (2004), p. 78; J. Staszewski, Problemy tolerancji, p. 237; idem, August II, p. 186; J. A. Gierowski, The Polish-Lithuanian Commonwealth in the $18^{\text {th }}$ Century, From Anarchy to Well-Organised State, (1996), p. 106. 
in the case of really important events, could last even a few dozen hours - as in the autumn of 1756, after the outbreak of the Seven Years' War, for the intention of restoring peace in Saxony and maintaining it in the Commonwealth ${ }^{7}$. A new type of pilgrimage was gaining in popularity, to locations related with patron saints of the Commonwealth and paintings or statues famous for miracles. The cult of patron saints developed in the Commonwealth, including St. Adalbert, St. Stanisław, St. Stanisław Kostka canonized in 1726, St. John Cantius (beatified 1676, canonized in 1767, but named the patron of Poland and Lithuania by Pope Clement XII in the year 1737) or Blessed John of Dukla (beatified in 1733) ${ }^{8}$. Above all, however, there was the cult of the Virgin Mary, with its visible symbol being the coronation of the painting of the Blessed Virgin Mary famous for miracles in the monastery in Jasna Góra on 8 September $1717^{9}$. This initiated a certain campaign for coronating other Marian images throughout the entire Commonwealth, not only in Catholic churches, but also in Uniate ones ${ }^{10}$.

7 Archiwum Główne Akt Dawnych w Warszawie (further: AGAD), Archiwum Radziwiłłowskie, dz. XXXIV, ms. 478, p. 15: Z Warszawy d. 29 7bris 1756; AGAD, Archiwum Publiczne Potockich, ms 180/5, p. 155-156: Z Warszawy d. 29 7bris 1756; Z Warszawy d. 8 Września; in: Kurier Polski, 1756, no CLXIV; W. Konopczyński, Polska $w$ dobie wojny siedmioletniej, 1: 1757-1758, (1909), p. 170.

8 Volumina legum. Przedruk zbioru praw staraniem XX. Pijarów w Warszawie, od roku 1732 do roku 1782, wydanego, ed. J. Ohryzko, 6 (1860), p. 295; J. Tazbir, Historia Kościoła Katolickiego w Polsce (1460-1795), (1966), pp. 162-165; J. Misurek, Stanisław Kostka, in: Encyklopedia Katolicka, 18: Serbowie - Szczepański, (2013), p. 731; J. Cegłowski, Św. Stanisław Kostka dawniej i dziś, (2007), pp. 45-47.

9 J. Rafałowiczówna, A z Warszawy nowiny te.... Listy do Elżbiety Sieniawskiej z lat 1710-1720, ed. B. Popiołek, (2000), pp. 117, 160-161: J. Rafałowiczówna do E. Sieniawskiej, Warszawa 21 XI 1715, 23 IX 1717; [E. Otwinowski], Dzieje Polski, p. 320; A. Witkowska, Pątnicze ośrodki maryjne na ziemiach Rzeczypospolitej w XVII w., in: Peregrinationes. Pielgrzymki w kulturze dawnej Europie, eds. H. Manikowska, H. Zarembska, (1995), pp. 204-209; K. W. Szwarocka, “Sarmacka bogini”. Kult maryjny w Polsce doby Baroku, (2010), pp. 113-139; T. Ciesielski, M. Sawicki, Pilgrimages of the Polish Gentry to Holy Places in the $17^{\text {th }}$ and the $18^{\text {th }}$ centuries, in: Biuletyn Polskiej Misji Historycznej = Bulletin der Polnischen Historischen Mission, 10 (2015), pp. 186-188.

10 T. Lipiński, Wiadomości historyczno-numizmatyczne o koronacyach obrazów Matki Bożej w dawnej Polsce, (1850), pp.9-36; M. Janocha, O koronacjach obrazów Matki Boskiej, in: J. S. Pasierb, M. Janocha, Polonica artystyczne w zbiorach watykańskich, (2000), pp. 186-190; J. Kurek, U schyłku panowania Augusta II Sasa, (2003), pp. 159-160; T. Ciesielski, Koronacje cudownych obrazów w osiemnastowiecznej Rzeczypospolitej, in: Cywilizacja prowincji Rzeczypospolitej szlacheckiej, eds. A. Jankowski, A. Klonder, (2004), pp. 195-212. 
The Marian cult became a significant element of the Sarmatian culture and the ideology of the bulwark of Christianity or rather Catholicism, also cultivated despite the obvious military weakness in the political arena of the Commonwealth. The increase in religious zealousness was connected with the rejection by the nobility in the middle of the $17^{\text {th }}$ century of the principle of equality of Christian denominations and the beginning of a process of increasing hostility towards non-Catholics, initially mostly the Protestants, and later the Orthodox Christians to ${ }^{11}$. This resulted in pushing the infidels in Poland and Lithuania to the position of second-class citizens as early as in the second half of the $17^{\text {th }}$ century, although before 1717 they exercised greater legal freedom than the Catholics in most protestant countries or in Russia ${ }^{12}$. This was guaranteed by the article on the freedom of religion confirmed for years starting in 1573. In 1696 the issue of freedom of religion was treated very marginally. Certain limitations on the rights of the Protestants were introduced in 1710, on the occasion of terminating all legal acts established during the reign of Stanisław I, although those regulations did not affect the infidels severely, being more of a loss of certain privileges obtained in 1705 thanks to the intercession of King Charles XII. The King of Sweden was undoubtedly the first among foreign monarchs to take care of the interests of the Protestants, not only Polish and Lithuanian ones, but also those from Silesia. However, he did not contribute to improve their position in the Commonwealth; on the contrary, he even contributed to the increase in hostility towards them from the Catholics. In 1716 they took the opportunity created by the limited reform of the constitutional law related to the termination of the Tarnogród Confederation, to limit the right of dissidents ${ }^{13}$. This was stipulated in articles II, IV and V of the Warsaw Treaty. The first one prohibited chancellors and sub-chancellors from confirming all royal grants for foreigners and non-Catholics, if that was to be at the expense of the Catholics. In reality, it meant that Protestants could not bear any titles or hold office in the Commonwealth. Article IV forbade

11 J. Feldman, Sprawa dysydencka za Augusta II, (1924), pp. 3-5; W. Kriegseisen, Ewangelicy polscy i litewscy, pp. 19-38.

12 J. A. Gierowski, The Polish-Lithuanian, pp. 57-59; J. Staszewski, Problemy tolerancji, p. 233-238; J. Kurek, U schyłku, pp. 160-162; J. Tazbir, Historia Kościoła, p. 167; S. Litak, Od Reformacji do Oświecenia. Kościół katolicki w Polsce nowożytnej, (1994), pp. 135-136.

13 J. Feldman, Sprawa dysydencka, pp. 5-15; W. Kriegseisen, Ewangelicy polscy i litewscy, pp. 43-44. 
celebrating dissident church services in places other than already existing churches ('congregations'), and at the same time the services were supposed to consist in quiet, individual prayers, without sermons or singing. Failure to comply with the ban was punished with fines, prison or exile for both the minister and participants in the illegal religious congregation. In practice, it also included non-Catholic funerals outside the congregation or the Orthodox Church. This introduced far reaching limitations on the freedom of religion, strengthened by the ban on employing clergy and teachers, and most of all of building and organizing new churches or chapels since 1717, not only in royal cities, where it had been applicable since 1632, but also in private towns and villages, or even noble houses. Importantly, there was no clear stipulation of what was to be considered an 'old' church, where silent service was allowed, whether this term referred to those erected before 1674 or 1632. Article V of the Treaty of Warsaw forbade accepting foreigners into military service and recommended that the number of Catholic officers should be greater than the dissidents ${ }^{14}$.

The legal regulations introduced in 1717 aimed at the elimination of followers of religions other than Roman Catholicism, mostly Protestants, from the public life of the Commonwealth. Although this was never expressed directly, the possibility of holding national offices or performing judicial functions was limited or even excluded. As for the former, it was completely successful, however, as early as in the middle of the $17^{\text {th }}$ century when Protestants or Orthodox Catholics did not hold ministerial or more significant senator offices, and holding any so-called dignitary offices was quite unusual. After 1717 even those became totally unavailable for non-Catholics. As for judiciary offices, the objective was to eliminate dissidents from tribunals by means of expanding the ban on selecting them as tribunal members in Sejmiks, in compliance with the articles of the Treaty of Warsaw. This was completely effective, as even in May 1717 during the Tribunal in Vilnius, five dissidents selected by the nobles of a few districts were deprived of their deputy positions: Stefan and Bogusław Michał Grabowski, Jan and Adam Wołk-Łaniewski, Aleksander Beniamin Abramowicz

14 Volumina legum, 6, pp. 119, 124-125, 127; W. Kriegseisen, Ewangelicy polscy i litewscy, p. 45; J. Kurek, U schyłku, pp. 171-172; J. Tazbir, Historia Kościoła, p. 150; W. Sawicki, Protestantyzm i odłamy religijne (1658-1795), in: Historia kościoła w Polsce, 1: do roku 1764, 2: od roku 1506, eds. B. Kumor, Z. Obertyński, (1974), p. 487. 
and Jakub Wołan ${ }^{15}$. Within the following years, non-Catholics were refused the right to be selected not only to become members of Tribunals, but also of town and land courts ${ }^{16}$.

Moreover, actions were taken in order to eliminate Protestants from class representation organs, which Catholics successfully obtained in 1718 . During the Sejm in Grodno, Andrzej Piotrowski, a Calvinist sword-bearer from Wielun, was deprived of the Parliament mandate, although he was rightfully selected during the Wielun Sejmik. It was initiated on the second day by Lithuanian deputies lead by an arbiter, reverend Jerzy Kazimierz Ancuta. Piotrowski protested against it, but was only supported, and not very firmly, by another deputy from Wieluń. In consequence, the Deputy House excluded Piotrowski as a dissident ${ }^{17}$.

This became a binding precedent for over 50 years and it only motivated non-Catholics to fight for their public rights for a brief time ineffectively, as proven by the interregnum in 1733. Firstly, over a dozen non-Catholic deputies were removed from the Convocational Sejm. Then, the articles of the confederation having guaranteed peace and safety to non-Catholics, they were banned from becoming deputies in Sejms and court and fiscal tribunals, holding dignitary, voivodeship, town and land offices. Neither could they be selected to become judges, sub-judges (subiudex) or clerks for town and land courts of law. The ban on gatherings and conventions of a religious nature was sustained, and furthermore, the non-Catholics were not permitted to seek the assistance or protection of other countries ${ }^{18}$. The anti-dissident regulations of 1717 and 1733 were approved by the Sejm in 1736 , which concluded the process of the non-Catholics' limitation of rights ${ }^{19}$.

15 J. Feldman, Sprawa dysydencka, pp. 15-16; W. Kriegseisen, Ewangelicy polscy i litewscy, p. 45.

16 J. Feldman, Sprawa dysydencka, pp. 12-13; W. Kriegseisen, Ewangelicy polscy i litewscy, pp. 187-226.

17 J. Feldman, Sprawa dysydencka, pp. 16-18; W. Kriegseisen, Ewangelicy polscy i litewscy, pp. 45, 241-242; J. Tazbir, Historia Kościoła, pp. 110-111; U. Kosińska, Sejm 1719-1720 a sprawa ratyfikacji traktatu wiedeńskiego, (2003), p. 220.

18 Volumina legum, 6, p. 286; W. Kriegseisen, Ewangelicy polscy i litewscy, pp. 46-47, 245-246.

19 W. Kriegseisen, Ewangelicy polscy i litewscy, p. 47. 
The Catholics did not achieve their goals everywhere. Despite their attempts, they failed to deprive the non-Catholics of their right to actively participate in the Sejmiks ${ }^{20}$. Moreover, the latter were not eliminated from small armies of the Commonwealth. The infidels constituted a significant group within the officers of infantry and dragoon officers. Moreover, in the 1720s, their number outgrew the Catholics, which was non-compliant with the provisions of article $\mathrm{V}$ of the Treaty of Warsaw ${ }^{21}$. The anti-dissident regulations also had little impact on the social relations in private estates. Their owners in their own best interest did not comply with the resolutions of the 1717 Sejm, including the Catholic ones who in Greater Poland (Wielkopolska), Pomerania or in the eastern voivodeships frequently supported their non-Catholic subjects. What is more, they appointed them as ministers and teachers, and in the eastern voivodeships during the reign of Augustus III there were cases where Orthodox churches were built on private estates 22 . The action of eliminating the Protestants from royal city councils was more successful, including the ones where dissidents constituted the more dominant group. The culminating point was the famous Torun case of 1724 .

The riots of 16-17 July between the Protestants and the Catholics resulted in wrecking the Jesuit college, desecrating the chapel, paintings and the tabernacle. The weak attitude of the magistrate dominated by the Protestants lead to the case being directed to the assessor court. It set up a special committee to investigate the case subsequently joined by assessors delegated by the Sejm. After an investigation lasting a few weeks and court proceedings lasting twenty days, on 16 November the assessor court sentenced 14 Protestants, including the president and mayor of Torun, to death. Nearly 50 other people were sentenced to imprisonment or severe

20 J. Feldman, Sprawa dysydencka, pp. 19-20; W. Kriegseisen, Ewangelicy polscy i litewscy, pp. 235-239; M. Zwierzykowski, Samorząd sejmikowy województw poznańskiego $i$ kaliskiego w latach 1696-1732, (2010), pp. 289-295, 307-308.

21 T. Ciesielski, Struktura narodowościowa kadry oficerskiej autoramentu cudzoziemskiego armii koronnej w latach 1717-1763 (prolegomena), in: Rzeczpospolita państwem wielu narodowości i wyznań. XVI-XVIII wiek, eds. T. Ciesielski, A. Filipczak-Kocur, (2008), pp. 541-544; idem, Szlachta pogranicza w wojsku koronnym w XVIII wieku. Przypadek rodu Lucke (Lukke), in: Szlachta - granice etniczne, wyznaniowe i cywilizacyjne, eds. T. Ciesielski, K. Mikulski, A. Korytko, (2016), pp. 131-132 and M. Zwierzykowski, Samorząd sejmikowy, p. 310 .

22 W. Kriegseisen, Ewangelicy polscy i litewscy, pp. 50-56, 67-121. 
fines. Lutherans from Torun were to pay high compensation to the Jesuits, fund a statue of the Virgin Mary, give one of their churches to the Catholics along with the monastery building and move their school outside the city walls. It was also decided that henceforth half of the city council members would be Catholics ${ }^{23}$.

This harsh sentence was executed almost in its entirety, with only two convicts managing to save their lives. This was approved by King Augustus, who after 1717 in disputes arising from religious matters either supported the Catholics or at least maintained a passive attitude ${ }^{24}$. The king and the states of the Commonwealth experienced how dangerous this was in 1724-1726. The severe sentence passed in the Torun case and execution of some of its decisions prompted Protestant countries and Russia to intervene in the interest of Polish dissidents. This was initiated by the King of Prussia and was not his first diplomatic statement defending the Protestants in the Commonwealth ${ }^{25}$. Since 1717 Frederick William I of Prussia had intervened regarding congregations in Lithuania and Greater Poland. Since the summer of $1713^{26}$ and since the following the spring of 1718 , Prussia was supported by British diplomacy, resulting not only in suspending the process of eliminating schools and churches, but also in returning some previously seized objects to the Protestant community ${ }^{27}$. However, this was

${ }^{23}$ [E. Otwinowski], Dzieje Polski, p. 341; S. Kujot, Sprawa toruńska z r. 1724, in: Roczniki Towarzystwa Przyjaciół Nauk Poznańskiego, 20 (1894), pp. 20-135; S. Salmonowicz, Sprawa toruńska z 1724 roku. Geneza i przebieg wydarzeń, in: idem, Szkice toruńskie z XVII i XVIII wieku, (1992), pp. 77-112; idem, W staropolskim Toruniu XVI-XVIII w. Studia i szkice, (2005), pp. 74-105 (chapter: Tumult toruński 1724 r. i jego mitologia); J. Dygdała, S. Salmonowicz, J. Wojtowicz, Między barokiem i oświeceniem (1660-1793), in: Historia Torunia, ed. M. Biskup, 2, 3 (1996), pp. 182-201; J. Staszewski, August II, pp. 228-229; J. Kurek, U schyłku, p. 180; A. Perłakowski, Jan Jerzy Przebendowski, p. 282; J. Tazbir, Historia Kościoła, pp. 151-152. The Torun tumult sparked a whole set of works by German historians presenting the pro-Prussian aspect, e.g. the already classic monography by F. Jakobi, Das Thorner Blutgericht 1724, (1896), pp. 1-143 or the relatively recently printed article by S. Hartmann, Die Polenpolitik König Friedrich Wilhelms I. von Preußen zur Zeit des "Thorner Blutgerichts" (1724-1725), in: Forschungen zur brandenburgischen und preuBischen Geschichte, Neue Folge 5 (1995), pp 31-58 (about tumult pp. 36-37).

24 J. Feldman, Sprawa dysydencka, pp. 22-23.

25 S. Kujot, Sprawa toruńska, pp. 120-121.

26 B. Krysztopa-Czupryńska, Rzeczpospolita, pp. 297-306

27 G. Rhode, England und das Thorner Blutgericht 1724, in: Historische Zeitschrift, 164 (1941), p. 505-508; S. Hartmann: Die Polenpolitik, pp. 35-36. 
only the case in southern and western districts of Greater Poland, where similarly to Royal Prussia and the estates owned by evangelical Lithuanian magnates, mostly the Radziwiłłs, the situation of the Protestants did not worsen significantly ${ }^{28}$. The King of Prussia, however, was not guided by selfless concern for the fate of the Lutherans or Calvinists, but his drive to weaken the position of Augustus II and Saxony in the Empire, so that he would gain control over the German Protestant world. Undoubtedly, both Frederick William and his successor since 1740 also meant to discredit the Polish-Lithuanian nobles, which could result in facilitating or justifying the annexationist ambitions of Prussia towards the Commonwealth especially since he defended the Protestants living in regions that the Prussian monarchs had wanted to include in their country for a few decades and their dreams finally materialized in $1772^{29}$. As for the British diplomacy, they attempted to at least appear disinterested, as they always invoked the British monarch's title of the defender of faith. In reality, however, George I was driven by benefits potentially gained in Germany and Great Britain as a result of defending the Protestants in Poland and Lithuania. In the Empire, Frederick William, as well as George I, as the ruler of the hereditary Electorate of Hanover wanted to enhance his status among the Protestant dukes at the expense of Augustus II, thus consolidating the status gained in 1692 along with the elector title. Another important issue was the legitimization of the bishoprics of Bremen and Verden, taken from Sweden in 1719 and incorporated into Hanover. In England the issue of discrimination of the Protestants in the Commonwealth was used as propaganda for fighting the Catholics and Jacobites desiring the restoration of the Stuarts ${ }^{30}$. The third state supporting the infidels in the Commonwealth was Russia. It mostly defended the Orthodox Church, whose rights guaranteed by the peace treaty of 1686 were not respected. Apart from using diplomatic means, Peter I also used his army stationed in Lithuania and Ukraine during the Great Northern War to repress the Unitarian church viewed as the main opponent of the Orthodox Church. The Tsar, while ferociously fighting the influence of the Orthodox Church in Russia especially its presence in the public

28 J. Feldman, Sprawa dysydencka, pp. 18, 25-29.

29 S. Hartmann: Die Polenpolitik, pp. 42-57.

30 B. Krysztopa-Czupryńska, Rzeczpospolita, pp. 297-340; G. Rhode, England, p. 511-528. 
sphere outside the country actively supported its existence and fought its enemies. In 1705 Peter I even participated in murdering a few monks and desecrating a Unitary Cathedral of Holy Wisdom in Polotsk ${ }^{31}$. Another issue was the destruction of land estates owned by the Unitarian Church and the St. Basil's Order in the eastern voivodeships of the Commonwealth, along with abducting the peasants living there to Russia. Peter I and his successors supported the Orthodox Church financially and diplomatically, since 1717 not only for religious reasons, but also political ones, as Peter I began using the dissident case to pressurize the Polish-Lithuanian nobility, mainly Augustus II, treating it as a part of vengeance for the King's political treason in concluding the anti-Russia Treaty of Vienna in $1719^{32}$. Therefore, it came as no surprise that in 1724 those three rulers were more than eager to take the opportunity created by the bloody case of the Protestants from Torun to intervene aggressively in Commonwealth affairs. This intervention was initiated by the King of Prussia, invoking the principles of the Treaty of Oliva guaranteeing the Polish and Lithuanian Protestants their rights and summoning the countries that were the guarantors of peace to take appropriate diplomatic steps ${ }^{33}$. Catholic France and Austria remained completely passive, while Sweden was very moderate, too $^{34}$. The Netherlands and mainly Great Britain, however, defended the Protestants very firmly. The latter, in a most expressive and categorical manner, demanded that the Assessor Sejm decisions should be mitigated and the rights the dissidents had enjoyed until 1717 be restored ${ }^{35}$. Peter I went the furthest, calling the guarantors of the Peace of Oliva to launch a military intervention. His death on 8 February 1725 resulted in such a threat vanishing, and the new ruler of Russia, Catherine I and her favourite Aleksandr Menshikov also

31 J. Oleszewski, Abrys domowej nieszczęśliwości y wnętrznej niesnaski, woyny Korony Polskiej i Wielkiego Xięstwa Litewskiego, ed. F. Kulczycki, (1899), pp. 37-39.

32 J. Feldman, Sprawa dysydencka, p. 24-25.

33 [E. Otwinowski], Dzieje Polski, p. 345; K. Jarochowski, Epilog sprawy toruńskiej, in: Roczniki Towarzystwa Przyjaciół Nauk Poznańskiego, 6 (1871), pp. 60, 63-64.

34 [E. Otwinowski], Dzieje Polski, pp. 345-346; J. Tazbir, Historia Kościoła, pp. 151-152.

35 [E. Otwinowski], Dzieje Polski, pp. 345-346; K. Jarochowski, Epilog sprawy toruńskiej, pp. 62-63, 64-67; B. Krysztopa-Czupryńska, Rzeczpospolita, pp. 319-335; A. C. Thompson, Britain, Hanover and the Protestant Interest, 1688-1756, (2006), pp. $101-120$. 
refrained from taking further diplomatic action ${ }^{36}$. The Commonwealth and the royal-electoral court was still subject to diplomatic pressure until the summer of 1726, mostly by Great Britain and the Netherlands. Finally, the conflict in the relations between the Commonwealth and the Protestant countries eased in the second half of 1726 under the influence of France and as a result of Frederick William's withdrawal, as he began to aim at an agreement with Augustus II and gain his will to cooperate regarding the German issue ${ }^{37}$.

The Torun case brought no benefits for the Polish King as far as the internal affairs were concerned, and his authority in the international arena suffered remarkably. The worst outcome, however, was in store for the Polish and Lithuanian dissidents, whose situation not only did not improve, but on the contrary, after the initial declarations of the King and the Senate of the Commonwealth regarding respecting the freedom of faith rights, the Catholic environment began to rebel, resulting in establishing laws limiting the dissidents' public rights during the Convocation Sejm in $1733^{38}$.

During the reign of Augustus III no such firm declarations were made in defence of dissident rights in the Commonwealth by the European countries. Great Britain almost completely withdrew from such actions, and their engagement in the Polish issues was practically nonexistent ${ }^{39}$. Prussia also limited its statements to defending specific individual congregations, and only used propaganda related to the violation of dissident rights in the Commonwealth during serious border conflicts, and even that only happened when the Polish Catholic Church was involved for example, when recruits were abducted for the Frederick's army from Church estates or during an infamous raid on a Catholic convent in Paradyż-Gościków in $1740^{40}$. Russia used the issue of violating the rights of the Orthodox

36 [E. Otwinowski], Dzieje Polski, p. 347; K. Jarochowski, Epilog sprawy toruńskiej, p. 60; J. Staszewski, August II, p. 229.

37 [E. Otwinowski], Dzieje Polski, pp. 346-347; S. Kujot, Sprawa toruńska, pp. 143-146; B. Krysztopa-Czupryńska, Rzeczpospolita, pp. 336-340; J. A. Gierowski, Dyplomacja polska doby saskiej (1699-1763), in: Historia dyplomacji polskiej, 2: 1572-1795, ed. Z. Wójcik, (1982), pp. 374-375; A. C. Thompson, Britain, pp. 120-124.

38 W. Sawicki, Protestantyzm, pp. 487-488.

39 P. Hanczewski, Dyplomacja brytyjska $w$ Europie Środkowo-Wschodniej $w$ latach 1748-1756. Misje w Berlinie, Dreźnie, Petersburgu i Wiedniu, (2001), pp. 137-165.

40 K. Jarochowski, Napad Brandenburczyków na klasztor paradyski w roku 1740, in: 
Church in a similarly instrumental manner. It was a means of exerting pressure on Polish and Lithuanian nobles, influencing the course of Sejm sessions, and mainly an argument in the border disputes where the Polish side usually mentioned the plundering of Catholic and Unitarian churches along with the abductions of peasants. On such occasions, Russian diplomats referred to the significant limitations of the role and property of the Orthodox Church that, instead of the four bishoprics stipulated in the peace treaty of 1686, only had one the bishopric of Belarus. Moreover, they lost many monasteries and temples only within the area under the jurisdiction of the Catholic bishop of Vilnius of 5 monasteries and 164 churches $^{41}$. The international relations in Europe and region had a serious impact on limiting the scale of interference of Protestant countries and Russia in the dissident issue in the Commonwealth, particularly the war between Russia, Austria and Turkey between 1736-1739 and the conflict between Prussia and Austria regarding Silesia that started in 1740. Augustus III as a Saxon elector was considered an ally of the fighting parties there, of Austria in 1741, then of Prussia for the following two years and in 1743 of Russia, which resulted in the countries most actively supporting the dissidents trying to maintain the best possible relations with Wettin. It was also important that the anti-dissident action in Poland gradually phased out after 1736. The Catholics were satisfied with the results thus far and the fact that the Protestants were marginalized in the country. The royal court was viewed as fully devoted to Catholicism, as proven by the ostentatious religiousness shown by Augustus III and his wife by, for example, organizing and participating in public religious services during their visits to Warsaw. There was also an important symbolic act of building a Catholic church

idem, Opowiadania i studia historyczne, (1887), pp. 119-140; T. Ciesielski, Pogranicze polsko-pruskie $w$ dobie wojny siedmioletniej, in: Komunikaty Mazursko-Warmińskie, 1 (259) (2008), p. 4.

${ }^{41}$ B. V. Nosov, Russkaâ politika v dissidentskom voprose v Pol’še 1762-1766 gg., in: Pol'ša i Evropa v X veke. Meždunarodnye vmutrennie faktory razdelov Reči Pospolitoj, ed. B. V. Nosov [Б.В. Носов, Русская политика в диссидентском вопросе в Польше 1762-1766 г2., in: Польша и Европа в Х веке. Международные вмутренние факторь разделов Речи Посполитой, еd. Б.В. Носов], (1999), pp. 25-35; М. Û. Anisimov, Semiletnââ vojna i rossijskâ̂ diplomatiâ v 1756-1763 gg., [М.Ю. Анисимов, Семилетняя война и российская дипломатия в 1756-1763 г2.], (2014), pp. 383-392; J. Tazbir, Historia Kościoła, p. 152. 
right next to the castle in Protestant Dresden ${ }^{42}$. Since that the way the Polish and Lithuanian nobility was perceived by? the royal court, the latter could afford to take some dissident friendly steps, for example, to organize in March 1750 a public Lutheran funeral for Major General Charles Friederick (Karl Friedrich) von Pöpelmann (died 14 February 1750) in Warsaw (the first in this city's history $)^{43}$.

Such limited concessions, however, had no impact on the improvement of the Commonwealth's and the royal court's image in Europe. The impact of the dissident discrimination on the image of the Commonwealth in Europe in the 1760s may be proven by short descriptions of Polish tolerance or the lack thereof made throughout the $16^{\text {th }}-18^{\text {th }}$ centuries by William Coxe and Frederick (Friedrich) Schulz. Englishman Coxe, who visited Poland in 1768 and viewed the ban of the dissidents' participation in the Sejm introduced in 1733 as the most important limitation of their rights $^{44}$. A far more precise description for the anti-dissident regulations of the Commonwealth states from the first half of the $18^{\text {th }}$ century was provided by German Frederick Schulz. In particular, he presented a detailed analysis of the provisions of the Treaty of Warsaw of 1716. As for the laws established in 1733 and approved in 1736, Schulz emphasized that those prevented non-Catholics from assuming court, public administration or military offices. Moreover, he mentioned that they were forbidden to seek protection with any rulers of other countries. Moreover, Schulz noticed that

42 Attempts to obtain specific concessions for the Catholics in Saxony, with particular focus on establishing in Dresden a Catholic church or at least a chapel at the electoral castle began in the moment Augustus II converted to Catholicism and claimed the Polish throne, that is in 1698. They were successfully completed in 1708 when in the former theatre building of John George II a Catholic chapel was established in Dresden. Despite the promises made by Augustus II, construction of a Catholic Church was never launched by the time of his death. In fact, it began on 28 July 1738 (preliminary works had been initiated in 1737), and the church of the Holy Trinity in Dresden was consecrated on 29 June 1751; J. Kopiec, Między Altransztadem a Poltawą. Stolica Apostolska wobec obsady tronu polskiego w latach 1706-1709, (1998), pp. 23-24, 53-54, 62, 106-109; J. Staszewski, Polacy w osiemnastowiecznym Dreźnie, (1986), pp. 30, 36-37.

43 J. Kitowicz, Pamiętniki, czyli Historia polska, eds. P. Matuszewska, Z. Lewinówna, (1971), pp. 53-54; T. Ciesielski, Pogrzeby wojskowe w czasach saskich, in: Wesela, chrzciny i pogrzeby w XVI-XVIII wieku, ed. H. Suchojad, (2001), pp. 221-222.

44 W. Coxe, Podróż po Polsce 1778, in: Polska stanisławowska w oczach cudzoziemców, ed. W. Zawadzki, 1 (1963), pp. 562-565. 
this legislation had an impact not only on the Protestants, but also on the Orthodox Church members ${ }^{45}$.

Although the legal situation of the infidels in the Commonwealth was no different than the status of the Catholics in most Protestant countries or in Russia, limitation of the freedoms of Polish and Lithuanian dissidents, mostly Protestant, only occurred as late as the first half of the $18^{\text {th }}$ century. In Western and Central Europe, the process of confessionalization had ended by the mid 1700s, and the second decade of the $18^{\text {th }}$ century recorded a growth in the significance of the Enlightenment ideology, applying a strong emphasis on religious tolerance. "Therefore it came as no surprise that the first generation of the European Enlightened disapproved of tendencies arising in Poland that they hoped to see irreversibly eliminated" 46 . The result would be the support of the European elites for diplomatic interventions defending the rights of the Protestants in the Commonwealth, and mainly for the Russian intervention in Poland in the 1760s, ending with restoration of the dissidents' rights in 1768 . The consequences of the process of limiting the rights of the dissidents lasting over half a century were very unfavourable for the Commonwealth, leading to an image being created of an archaic, ultra-Catholic, very weak country unable to solve its internal issues on their own. Such an image, consolidated during the Confederation of Bar, was a major factor contributing to the fact that most European public opinion approved the act of the first partition.

Translated by Joanna Drosik

${ }^{45}$ F. Schulz, Podróże Inflantyczka z Rygi do Warszawy i po Polsce w latach 1791-1793, in: Polska stanisławowska, 2, pp. 628-633.

46 W. Kriegseisen, Ewangelicy polscy i litewscy, p. 49. 


\section{GDY INNI WŁADCY BRONIĄ DYSYDENTÓW \\ SYTUACJA PROTESTANTÓW I PRAWOSŁAWNYCH W RZECZYPOSPOLITEJ CZASÓW SASKICH}

STRESZCZENIE

W artykule został przedstawiony problem ograniczania praw protestantów i wyznawców innych religii chrześcijańskich niż katolicka w okresie panowania dwóch królów z dynastii Wettynów, Augusta II (1697-1733) i Augusta III (1733-1763). Proces ten został zainicjowany jeszcze w drugiej połowie XVII wieku, ale dokonał się w latach 1717-1736. W artykule omówiono uchwały sejmów oraz inne akty prawne wprowadzone $\mathrm{w}$ tym czasie, których celem było wyeliminowania innowierców z życia publicznego. Odbywało się to przy biernej postawie królów polskich. Protestantom i prawosławnym pomocy udzielali władcy niekatolickich państw europejskich: Prus, Rosji i Wielkiej Brytanii.

\section{WENN ANDERE HERRSCHER DIE DISSIDENTEN IN SCHUTZ NEHMEN}

\section{Die SituATION DER PROTESTANTEN UND RUSSISCH-ORTHODOXEN IN SACHSEN-POLEN}

\section{ZUSAMMENFASSUNG}

Der vorliegende Beitrag schildert die Einschränkung der Rechte von Protestanten und anderen nichtkatholischen Christen während der Herrschaftszeit zweier Könige aus der Wettiner-Dynastie, August II. (1697-1733) und August III. (1733-1763). Dieser Prozess begann schon in der zweiten Hälfte des 17. Jahrhunderts, vollzog sich aber letztendlich in den Jahren 1717-1736. Im Beitrag werden die Gesetzgebung des polnischen Sejms und andere zeitgenössische Rechtsakte geschildert, mit deren Hilfe beabsichtigt wurde, die Andersgläubigen aus dem öffentlichen Leben auszuschließen. Und dies erfolgte bei einer grundsätzlich passiven Haltung der polnischen Könige. Den Protestanten und Russisch-Orthodoxen kamen die Herrscher der nichtkatholischen europäischen Länder wie Preußen, Russland und Großbritannien zu Hilfe.

Übersetzt von

Liliana Lewandowska

\section{WHEN OTHER RULERS DEFEND DISSIDENTS}

THE SITUATION OF PROTESTANTS AND ORTHODOX CHRISTIANS IN THE POLISH-LITHUANIAN COMMONWEALTH OF THE SAXON ERA SUMMARY

The article addresses the problem of limiting the rights of Protestants and other non-Catholic Christian denominations during the reigns of two kings from the 
Wettin dynasty - King Augustus II (1697-1733) and King Augustus III (17331763). The process started as early as the second half of the $17^{\text {th }}$ century, but it was fully accomplished in the years 1717-1736. In the article the author discusses the resolutions of the sejms and other legal acts introduced at that time, the aim of which was to eliminate dissenters from public life. The Polish monarchs were inert towards the process. It was the rulers of non-Catholic European states (Prussia, Russia and Great Britain) that helped Protestants and Orthodox Christians in Poland.

\author{
Translated by \\ Agnieszka Chabros
}

\title{
SŁOWA KLUCZOWE / SCHLAGWORTE / KEYWORDS
}

- XVIII wiek; Rzeczpospolita Obojga Narodów; katolicyzm; protestantyzm; prawosławie; tolerancja i nietolerancja religijna; kult maryjny i świętych

- 18. Jahrhundert; Königliche Republik der polnischen Krone und des Großfürstentums Litauen; Katholizismus; Protestantismus; Orthodoxie; religiöse Toleranz und Intoleranz; Marien- und Heiligenverehrung

- the $18^{\text {th }}$ century; the Polish-Lithuanian Commonwealth; Catholicism; Protestantism; Orthodoxy; religious tolerance and intolerance; the worship of the Blessed Virgin Mary and the saints

\section{BIBLIOGRAFIA / BIBLIOGRAFIE / BIBLIOGRAPHY}

\section{ŹRÓDłA ARCHIWALNE / ARCHIVALISCHE QUELLEN / ARCHIVAL SOURCES}

Archiwum Główne Akt Dawnych w Warszawie, Archiwum Publiczne Potockich, ms 180/5. Archiwum Główne Akt Dawnych w Warszawie, Archiwum Radziwiłłowskie, dz. XXXIV, ms. 478.

\section{ŹRÓDŁA DRUKOWANE / GEDRUCKTE QUELLEN / PRINTED SOURCES}

Coxe W., Podróż po Polsce 1778, in: Polska stanisławowska w oczach cudzoziemców, ed. W. Zawadzki, 1 (1963), pp. 559-703.

Kitowicz J., Pamiętniki, czyli Historia polska, eds. P. Matuszewska, Z. Lewinówna, (1971). Kurier Polski, CLXIV (1756).

Oleszewski J., Abrys domowej nieszczęśliwości y wnętrznej niesnaski, woyny Korony Polskiej

$i$ Wielkiego Xięstwa Litewskiego, ed. F. Kulczycki, (1899).

[Otwinowski E.], Dzieje Polski pod panowaniem Augusta II od roku 1696-1728, [ed. A. Mułkowski], print J. Czech, (1849).

Rafałowiczówna J., A z Warszawy nowiny te... Listy do Elżbiety Sieniawskiej z lat 17101720, ed. B. Popiołek, (2000). 
Schulz F., Podróże Inflantyczka z Rygi do Warszawy i po Polsce w latach 1791-1793, in: Polska stanisławowska w oczach cudzoziemców, ed. W. Zawadzki, 2 (1963), pp. 381-673. Volumina legum. Przedruk zbioru praw staraniem XX. Pijarów w Warszawie, od roku 1732 do roku 1782, wydanego, 6 and 7, ed. J. Ohryzko, (1860).

\section{LITERATURA / LITERATUR / LITERATURE}

Anisimov M. U.., Semiletnââ vojna i rossijskaâ diplomatiâ v 1756-1763 gg. [Анисимов М. Ю., Семилетняя война и российская дипломатия в 1756-1763 г2.], (2014).

Cegłowski J., Św. Stanisław Kostka dawniej i dziś, (2007).

Ciesielski T., Koronacje cudownych obrazów w osiemnastowiecznej Rzeczypospolitej, in: Cywilizacja prowincji Rzeczypospolitej szlacheckiej, eds. A. Jankowski, A. Klonder, (2004), pp. 195-212.

Ciesielski T., Pogranicze polsko-pruskie $w$ dobie wojny siedmioletniej, in: Komunikaty Mazursko-Warmińskie, 1 (259), (2008), pp. 3-17.

Ciesielski T., Pogrzeby wojskowe w czasach saskich, in: Wesela, chrzciny i pogrzeby w XVIXVIII wieku, ed. H. Suchojad, (2001), pp. 217-233.

Ciesielski T., Sawicki M., Pilgrimages of the Polish Gentry to Holy Places in the $17^{\text {th }}$ and the $18^{\text {th }}$ centuries, in: Biuletyn Polskiej Misji Historycznej = Bulletin der Polnischen Historischen Mission, 10 (2015), pp. 181-196.

Ciesielski T., Struktura narodowościowa kadry oficerskiej autoramentu cudzoziemskiego armii koronnej w latach 1717-1763 (prolegomena), in: Rzeczpospolita państwem wielu narodowości i wyznań. XVI-XVIII wiek, eds. T. Ciesielski, A. Filipczak-Kocur, (2008), pp. 541-559.

Ciesielski T., Szlachta pogranicza $w$ wojsku koronnym $w$ XVIII wieku. Przypadek rodu Lucke (Lukke), in: Szlachta - granice etniczne, wyznaniowe i cywilizacyjne, eds. T. Ciesielski, K. Mikulski, A. Korytko, (2016), pp. 131-148.

Dygdała J., Salmonowicz S., Wojtowicz J., Między barokiem i oświeceniem (1660-1793), in: Historia Torunia, ed. M. Biskup, 2, 3 (1996).

Dżuma, ospa, cholera: $w$ trzechsetnq rocznice wielkiej epidemii w Gdańsku i na ziemiach Rzeczypospolitej w latach 1708-1711, ed. E. Kizik, (2012).

Feldman J., Sprawa dysydencka za Augusta II, (1924).

Flis S., Dżuma na Mazurach $i$ Warmii w latach 1708-1711, in: Komunikaty Mazursko-Warmińskie, 4 (1960), pp. 473-523

Frost R. I., The Northern Wars, War, State and Society in Northeastern Europe, 1558-1721, (2000).

Giedroyć F., Mór w Polsce w wiekach ubiegłych. Zarys historyczny, (1899).

Gierowski J. A., Anglia wobec konwersji królewicza Fryderyka Augusta, in: Kultura staropolska - kultura europejska. Prace ofiarowane Januszowi Tazbirowi w siedemdziesiata rocznice urodzin, eds. S. Bylina et al., (1997), S. 127-138.

Gierowski J. A., Dyplomacja polska doby saskiej (1699-1763), in: Historia dyplomacji polskiej, 2: 1572-1795, ed. Z. Wójcik, (1982), p. 331-481.

Gierowski J. A., Między saskim absolutyzmem a złotą wolnością. Z dziejów wewnętrznych Rzeczypospolitej w latach 1712-1715, (1953).

Gierowski J. A., Na szlakach Rzeczypospolitej w nowożytnej Europie, (2008). 
Gierowski J. A., The Polish-Lithuanian Commonwealth in the $18^{\text {th }}$ Century, From Anarchy to Well-Organised State, (1996).

Hanczewski P., Dyplomacja brytyjska w Europie Srodkowo-Wschodniej w latach 1748-1756. Misje w Berlinie, Dreźnie, Petersburgu i Wiedniu, (2001).

Hartmann S., Die Polenpolitik König Friedrich Wilhelms I. von Preußen zur Zeit des "Thorner Blutgerichts" (1724-1725), in: Forschungen zur brandenburgischen und preußischen Geschichte, Neue Folge 5 (1995), pp 31-58.

Jakobi F., Das Thorner Blutgericht 1724, (1896).

Janocha M., O koronacjach obrazów Matki Boskiej, in: J. St. Pasierb, M. Janocha, Polonica artystyczne w zbiorach watykańskich, (2000), pp. 186-190.

Jarochowski K., Epilog sprawy toruńskiej, in: Roczniki Towarzystwa Przyjaciół Nauk Poznańskiego, 6 (1871), pp. 58-67.

Jarochowski K., Napad Brandenburczyków na klasztor paradyski w roku 1740, in: idem, Opowiadania i studia historyczne, (1887), pp. 119-140.

Karpacz E., "Opłakane czasy" - epidemia dżumy w Krakowie w latach 1707-1710. Przyczynek do badań nad upadkiem królewskiego miasta, in: Folia Historica Cracoviensia, 18 (2012), pp. 239-256.

Konfederacja tarnogrodzka i jej tradycje, ed. R. Szczygieł, (1995).

Konopczyński W., Polska $w$ dobie wojny siedmioletniej, 1: 1757-1758, (1909).

Kopiec J., Między Altransztadem a Połtawa. Stolica Apostolska wobec obsady tronu polskiego w latach 1706-1709, (1998).

Kosińska U., Sejm 1719-1720 a sprawa ratyfikacji traktatu wiedeńskiego, (2003).

Kracik J., Pokonać czarnq śmierć, Staropolskie postawy wobec zarazy, (1991).

Kriegseisen W., Between Intolerance and Persecution: Polish and Lithuanian Protestants in the $18^{\text {th }}$ Century, in: Acta Poloniae Historica, 73 (1996), pp. 13-27.

Kriegseisen W., Ewangelicy polscy i litewscy w epoce saskiej (1696-1763). Sytuacja prawna, organizacja i stosunki międzywyznaniowe, (1996).

Krysztopa-Czupryńska B., Rzeczpospolita w oczach dyplomatów brytyjskich w pierwszej połowie XVIII wieku, (2013).

Kujot S., Sprawa toruńska z r. 1724, in: Roczniki Towarzystwa Przyjaciół Nauk Poznańskiego, 20 (1894), pp. 3-152.

Kurek J., U schyłku panowania Augusta II Sasa, (2003).

Lipiński T., Wiadomości historyczno-numizmatyczne o koronacyach obrazów Matki Bożej $w$ dawnej Polsce, (1850).

Litak S., Od Reformacji do Oświecenia. Kościól katolicki w Polsce nowożytnej, (1994).

Misurek J., Stanisław Kostka, in: Encyklopedia Katolicka, 18: Serbowie - Szczepański, (2013), p. 730-732.

Nosov B. V., Russkaâ politika v dissidentskom voprose v Pol'še 1762-1766 gg., in: Pol’ša $i$ Evropa v XVIII veke. Meždunarodnye vmutrennie faktory razdelov Reči Pospolitoj, ed. В. V. Nosov [Носов Б. В., Русская политика в диссидентском вопросе в Польше 1762-1766 г2., in: Польша и Европа в XVIII веке. Международные вмутренние факторы разделов Речи Посполитой, еd. Б. В. Носов], (1999), pp. 25-46.

Perłakowski A., Jan Jerzy Przebendowski jako podskarbi wielki koronny (1703-1729), (2004). 
Prochaska A., Konfederacja tarnogrodzka, in: Przewodnik Naukowy i Literacki. Dodatek do “Gazety Lwowskiej”, 45 (1917), 1: pp. 50-61, 2: pp. 140-154, 3: 239-256, 4: 353-367, 5: 430-454, 6: 521-548, 7: 638-657, 8: 756-768, 9: 837-848, 10: 934-942, 11: pp. 10301040.

Rhode G., England und das Thorner Blutgericht 1724, in: Historische Zeitschrift, 164 (1941), pp. 496-528.

Salmonowicz S., Sprawa toruńska z 1724 roku. Geneza i przebieg wydarzeń, in: idem, Szkice toruńskie z XVII i XVIII wieku, (1992), pp. 77-112.

Salmonowicz S., W staropolskim Toruniu XVI-XVIII w. Studia i szkice, (2005), pp. 74-105.

Sawicki W., Protestantyzm i odłamy religijne (1658-1795), in: Historia kościoła $w$ Polsce, 1: do roku 1764, 2: od roku 1506, eds. B. Kumor, Z. Obertyński, (1974), p. 485-489.

Sieńkowski E., Dżuma w Gdańsku w 1709 roku. Studium $z$ dziejów epidemiologii, in: Archiwum Historii Medycyny, 33 (1970), pp. 309-401.

Staszewski J., August II Mocny, (1998).

Staszewski J., August III Sas, (2010).

Staszewski J., Polacy w osiemnastowiecznym Dreźnie, (1986).

Staszewski J., Problemy tolerancji polskiej w czasach saskich, in: idem. "Jak Polskę przemienić w kraj kwitnący...”. Szkice i studia z czasów saskich, (1997), pp. 232-242.

Szwarocka K. W., "Sarmacka bogini”. Kult maryjny w Polsce doby Baroku, (2010).

Tazbir J., Historia Kościoła Katolickiego w Polsce (1460-1795), (1966).

Tazbir J., Państwo bez stosów. Szkice z dziejów tolerancji w Polsce XVI i XVII wieku, (1967).

Thompson A. C., Britain, Hanover and the Protestant Interest, 1688-1756, (2006).

Wimmer J., Wojsko Rzeczypospolitej w dobie wojny pótnocnej (1700-1717), (1956).

Witkowska A., Pątnicze ośrodki maryjne na ziemiach Rzeczypospolitej w XVII w., in: Peregrinationes. Pielgrzymki w kulturze dawnej Europie, eds. H. Manikowska, H. Zarembska, (1995), pp. 204-209.

Zwierzykowski M., Samorząd sejmikowy województw poznańskiego i kaliskiego w latach 1696-1732, (2010). 
